\title{
In the Realm of Comrades? Scattered Thoughts Occasioned by the Centenary of the Founding of the Chinese Communist Party, 1921-2021
}

\author{
Rebecca E. Karl
}

\begin{abstract}
This brief essay meditates on the advent of the ideal of horizontal social relations, exemplified in the early CCP years in the political term, "comrade" (tongzhi). It takes up Qu Qiubai as exemplary of a Marxist political thinker whose commitments to horizontality/comrade relations can be illustrated through his theories of literature, translation and language. It proposes that despite Xi Jinping's recent rhetorical admonishments to re-activate "comrade" as a political term, it is the LGBTQ community's appropriation of "comrade" in contemporary China that actually holds the potential for a substantive reanimation of the utopian ideals begun a century ago.
\end{abstract}

Keywords: Marxism; comrade; horizontal social relations; Qu Qiubai; LGBTQ; China Communist Party

On his deathbed in 1925, Sun Yat-sen 孙中山 wrote in his last will and testament an exhortation to his followers: "The revolution is not yet finished; comrades, we must continue our efforts" (geming shangwei chenggong, tongzhi rengxu nuli 革命 尚未成功, 同志仍需努力). In this modern political usage of the term comrade (tongzhi 同志), Sun hailed into being a collectivity defined through and by a common (tong 同) will (zhi 志) as a principle of revolutionary relations and of future-oriented historical struggle and activity. Sun's exhortation to continue "the revolution" - a series of movements that, from the 1910s through to this day, has been a site of violent social-state struggle and of repeated interpretive contestation - through the collective political agency of the relation known as "comrade" was taken up by Communists in China, under the aegis of the Chinese Communist Party (CCP). While there was already, in the early 1920s, a circulation of the notion of "comradeship" derived from the Russian Revolution and its socialist practice (named by the Russian term tovarishch), in China, where strict family, gender, ethnic and cultural hierarchies had served

* History Department, New York University, New York, USA. Email: rek2@nyu.edu. 
most frequently to mark and regulate social and political relationships, the coming into wider usage of the egalitarian moniker and relation tongzhi is of particular note. Qu Qiubai 䨉秋白, an early Marxist and communist, can be considered an important figure in this history. I will use his concept of "absolute vernacular" (juedui de baihua 绝对的白话) to think about the significance of excavating the "comrade" relation as a core promise of early political commitments to communism in China. The emergence of the political relation indicated by "comrade" can serve as a way to think about the centenary of the founding of the Chinese Communist Party, even as its dissolution as a political principle of communist activity after the 1980s bequeathed its horizontal ideals to the reinvention of "comrade" as a community-in-common for LGBTQ activists.

In a Sinological mode, one perhaps could link the egalitarianism of "comrade" to the "friend" relation in the Confucian social order. Indeed, as any introductory lecture on so-called traditional Chinese socio-cultural matters might note, of the five relations that ideally regulate a well-ordered (hierarchical) society in the Confucian tradition, the "friend" relation is the only horizontal one. It was elevated most famously in the modern moment of desired social re-alignments at the end of the Qing dynasty by Tan Sitong 谭嗣同, who was soon to become a martyr to the 1898 petition and reform movement. Tan linked his advocacy of the "friend" relation irrevocably to the reimagined social goal of ren 仁 (humaneness), a core Confucian value. Yet however appealing the "friend," or ren, protoliberal position might be - and it has been hailed more recently as a "Chinese" solution to capitalism's depravities and injustices - "comrade" is a different kind of naming and a different kind of relation altogether. For that reason, even while Liang Qichao's 梁启超 usage, also dating from 1898, indicates a will towards transformative action, the appearance of the term tongzhi in any of its late 19th-century/early 20th-century iterations cannot be understood in the modern sense of "comrade" as a political category of chosen collective social activity.

For example, Liang wrote: "Those of my countrymen who are unable to sacrifice themselves to save the state are burdened by either their families or their own bodies. I wish to proclaim the following: we cannot save the state unless we are prepared for our families to be destroyed; we cannot achieve our righteous cause if we are unwilling to sacrifice ourselves. Sharing this commitment [to sacrifice] can be called being common-willed (tongzhi)." ${ }^{1}$ Here, in Liang's heroic version, tongzhi is a collective of individuals acting on a putative common will to die for the state (guo 国) as a sacrifice either of body and/or of family. It does not indicate a horizontal political organizational principle. Harking to the notion of individual heroism - the yingxiong/ haojie 英雄、豪杰 figure so beloved in that time, when many wrote enthusiastically about the self-sacrifice of the righteous hero - Liang's tongzhi designation is not a collective figure (or a figure of a collective) but rather a collection of heroic individuals. By the same token, in 
the first decade of the 20th century, Qiu Jin 秋瑾 also was looking to think her way through particular forms of hierarchy to a fundamentally different way of social being. She wrote fictionally of (elite) women forming "sisterhoods" to escape the constraining confines of their patriarchally organized cloistered lives, looming arranged marriages and footbound or immobile existences. ${ }^{2}$ These sisterhoods were explicitly articulated as exclusive to elite cloistered women - a horizontality that maintained the social hierarchy between such women and their servants, for example, and that could not yet contemplate gendered identification beyond the confines of a very particular classed lifeworld. Indeed, it would be another decade and a half before the "comrade" relation would detach itself from an extant state in China, and from an extant class relation, to expand socially to encompass those from a different social class and background and begin to become the revolutionary principle of a more radical political collective in action that opposed the hitherto existing states-of-being whether social, cultural, economic or political.

A "comrade," thus, is not a "friend" - neither commonly understood, nor in the radical Confucian tradition, and even less in the Schmittian agonistic idiom, in which "friend" indicates a shifting alliance against a shifting "enemy" rather than a necessary revolutionary politics conditioned by a necessary ideological commitment. It is also not merely a convenient substitution for a more formal salutation, nor only a cultural form of politeness. ${ }^{3}$ Nor is it a sisterhood or a heroic individual sacrificial position of spectacular opposition. Rather, it is explicitly politically disciplined as a collectively envisioned futureoriented possibility of social organization actively pursued in the present through horizontal relationality. Thus, "comrade" points to a principle of collectivity that, however affective, in Jodi Dean's words, shifts us "away from the suppositions of unique particularity." "It can be thought, in Qu Qiubai's terms, as an "absolute vernacular" to which political mobilization for socialist revolution must answer and through which such mobilization must be expressed. That is, the tongzhi relation, when evoked, must be intelligible, not merely as vocabulary but as a form of political sociality.

In a discursive genealogy of the usage of tongzhi/comrade in Chinese political life, the historian Ma Mingchong 马明冲 has demonstrated that tongzhi displaced such labels as tongbao 同胞 (compatriot), tongxue 同学 (classmate), or jiemei 姐妹 (“sister”) and xiongdi 兄弟 (“brother”), or xiansheng 先生 (mister). 5 Ma argues that by 1923, "comrade" was on its way to becoming more universally used among Communist and Nationalist Party members, and that after Sun Yat-sen's 1925 usage, noted above, the label become more ubiquitous. By 1927, Ma notes, most documents issued by the CCP used the phrase

3 On "comrade" as salutation and politeness, see Kohlenberg 2016.

4 Dean 2019, 15.

5 Ma 2018. 
gewei tongzhi 各位同志 (all comrades) in referring to those subject to Party discipline, and by 1930, the "differentiation between 'comrade' and 'mister' had become more clearly defined" in social usage, to encompass the social classes who were deemed part of a potential revolutionary totality. As Ma puts it, comrade was no longer merely a salutation but indicated adherence to an "ism" (zhuyi 主义). Further, with the Kuomintang (KMT)/CCP split in 1927, the guiding principle became: those who believe in Marxism are comrades (makesi zhuyi de xinyangzhe shi “tongzhi” 马克思主义的信仰者是 “同志”).

Ma's research in Party discourse history valuably explains how "comrade" became a political identification through the 1920s. This identification was not limited by nationality or gender, although it became over the course of approximately a decade an exclusionary form for indicating loyalty to the Communist Party. It was a principle of Bolshevism, therefore, that allowed for political work to proceed among like-minded people in a precarious historical context filled with political, capitalist and imperialist violence; it was a principle among those subjecting themselves to Party discipline; and, thus, it was a principle that necessitated an individual subordination to the Party as the leader of a collective revolutionary endeavour. In this sense, it cleared a non-hierarchical possibility for political work on the ground while also imposing a vertical relationship between a central Party whose ideological propositions were to be promoted by being disseminated downwards through a hierarchically designed Party structure. The contradictions and tensions were what made "comrade" a valued principle of politics, even while it was also always a problem in and of everyday individual practice.

\section{"Dear Comrade"}

Qu Qiubai, an important Marxist intellectual and early participant in the CCP as theorist, translator and short-time reluctant Party leader, was deeply engaged in conceptualizing horizontal, non-hierarchical political, social and cultural relationships for the duration of his adult life in politics and letters. A symptomatic excavation of the possibilities for such relations in China's 1920s and 1930s can indicate how a process and practice of egalitarian politics as a social norm and desire - expressed in the concept of "comrade" - could be conceptualized in the context of a particular precarious moment of history. ${ }^{6}$ In this sense, it should be obvious that the ideal of non-hierarchical relations was practised substantively only rarely at any level of organizational work; it should also be noted that such an idealized conceptualization thus functioned mainly discursively in the everyday life of the Party elite - calling each other "comrade" was both ubiquitous and hence also only selectively practised among those recognized as being worthy of the designation. Nevertheless, we can recall that "comrade" named a real

6 "Symptomatic" indicates a form of reading that thwarts surface interpretation. It is a critical exploration for a "latent meaning behind a manifest one." It does not extend to comprehensive coverage. Jameson 1981,60 . 
aspiration, one that seemed, in the 1920s and 1930s, urgent and possible to attain in the now and as part of a longer-term process of fashioning a better future.

Below, I will examine briefly three examples of Qu's lived, practised and articulated commitment to horizontal non-hierarchy. First, and most abstractly, such a commitment includes his (modest? rhetorical?) stated anxieties about superfluidity. Qu often maintained that he was a "superfluous man," in the 19th-century Russian literary fashion. His last piece of writing before his execution by the Nationalists in 1935 is famously entitled Superfluous Words (Duoyu de hua 多于的话). ${ }^{7} \mathrm{Qu}$ styled himself superfluous because, as he put it, his "dilettantish" delight in literature ultimately did not square with the spartan requirements of a historically mandated proletarian politics. This conflict, for $\mathrm{Qu}$, is a materialist problem and not one of abstract sociological categorization or of personal psychological malaise. To be sure, Qu's claims to superfluidity most often have been read by scholars as a personal attribute, and more generally as a stand-in for the supposed always-already ill-fit between intellectuals and the Chinese Communist revolutionary movement. ${ }^{8}$ No doubt, Qu's lament about the incongruity between his own desires and the demands of his times was an articulation of his personal preference to read and write over the discipline and drudgery of political work. ${ }^{9}$ Many a Marxist and Communist Party-affiliated intellectual lamented this clash between the individual desire for self-contemplation and the collective commitment to mass politics. ${ }^{10}$ In this vein, Tani Barlow sympathetically reads Qu's last testament as articulating an abjection in his willingness to die "for logos in translation." 11

My interest in Qu's self-styling as superfluous is slightly different to Barlow's, however. ${ }^{12}$ I want to propose that we think about how superfluidity can be read as a political statement in pursuit of comradeship. In this light, it is possible - and I think eminently plausible and historically necessary - to understand the "superfluous" in Qu's lament as articulating an actually existing materialist problem of how to practise non-hierarchical political relations in a historical moment where hierarchy is the social norm. In this way, we can read superfluidity as expressing both the promise and the peril of revolutionary organization and mobilization, the individual sense of both alienation and obligation simultaneously. This "both/and" problem is most overtly stated, in Qu's final text, as a

7 Qu 2006[1935]. The text was originally written in May 1935, partially published soon after Qu was executed, and then published in full in 1937.

8 Possible citations here are voluminous. I'll just note Paul Pickowicz 1981; and from an entirely different political perspective, Nick Knight 2005.

9 See Jamie Greenbaum's introduction to Qu 2006[1935], for example. Also see Rodekohr 2017, 400-406.

10 For example, Bensaiid 2015. A French Marxist-Communist, Bensaiid writes often in his memoirs of a similar form of unease. As he remarks at one point: "I simply became, by the chance of circumstances, a 'teacher of philosophy' and a red hussar of the Republic" (47), a happenstance that causes tension and emotional distress, even while it becomes a life purpose. Gramsci wrote of this conflict often in his Prison Notebooks.

11 Barlow 2016.

12 I should note that my reading of $\mathrm{Qu}$ is perhaps closest to that of Alain Roux, who, in his "A revolution too far," takes very seriously a radical interpretation of Qu and his endeavour. (Roux and Wang 2006). 
"petit-bourgeois intellectual's disposition," in the service of a "historical misunderstanding." 13 By reading "misunderstanding" against the normative academic grain, one can go beyond the psychologizing and sociological fixities to think about superfluidity as expressing not merely an anxiety nor only a sense of extraneousness or class identification with a given position, but rather a wistful and yet boldly accepted certainty about the loss of discursive hegemony. That is, in the conditions of revolution, intellectuals cannot produce all knowledge and nor should they pretend that they should or can. This understanding presents the possibility of a historical materialist reading, where superfluidity in revolutionary times is about being exiled from one's own life - for example, being an intellectual desiring solitude and study but pushed by historical circumstances to be a Communist organizer among peasants or the proletariat. It is about the experience of displacement from so-called proper sociological categories in historical terms. ${ }^{14}$ At the same time, superfluidity in revolutionary terms is also about the realization that the supposed "proper" monologic relation of knowing self to ignorant other - for example, intellectual to proletarian - must be actively troubled and thoroughly reconfigured. ${ }^{15}$ The discursive and thus lived relation cannot remain at the level of dominant/dominated or elite/subaltern.

Superfluidity is about posing the questions: who can speak? And for whom/ when? It is about not having the answers to such questions, even if the conditions of superfluidity also insistently propose that the only possible political position is continually to raise these questions as a core problem of social and political analysis and mass revolutionary activity. Qu posed these questions without pretending he - or really anyone - could solve in any definitive way, either discursively or in practice, the historical problem of the relationship between the petty bourgeois desire to read and write and proletarian historical revolutionary necessity. One could merely strive and confront the conundrum as a daily problem of producing new forms of sociality. The excess - that which reaches beyond the self - or, that is, the striving could be called the striving towards "comrade." This conundrum, or contradiction we could say, was the condition both of Qu's possibility and his impossibility as a political actor. What Qu reaches for in raising superfluidity, then, is an acknowledgement of the necessity to try for dialogic relations in politics and discursive forms - to attempt to live life as a comrade across classes and with revolutionary politics in command - albeit with failure always a looming and probable potential.

This conviction about the need to work from the remaindered excess, to practise life dialogically and non-hierarchically, rather than monologically and vertically - this willingness, in other words, to be alienated from one's proper place in order to politically connect to others - also suffused Qu's other

14 For a powerful articulation of the political and theoretical stakes in reading for displacement not sociological placement, see Ross 2002.

15 See Patterson 1995, 3-6. 
commitments. So, second, we can cite Qu's conviction that a horizontal form of "proletarian language," forged from the relations established within factories in urban industrial spaces from among those who spoke differently accented and pronounced versions of "Chinese," was the only kind of language reform worth working towards. This concern with language emerged in part through the wider discussions on language reform then ongoing among Chinese intellectuals. ${ }^{16}$ It also emerged from Qu's understanding of "socialism" as being defined, first and foremost, by the abolition of the regime of private property. ${ }^{17}$ That is, Qu's commitments on language reform required that such reform take into account the equal claims on "Chinese" of regional languages and pronunciations, rather than override such concerns with a hegemonic standardizing form derived from the northern dialect. This commitment is very much aligned with, and perhaps even derivative of, his political understanding of socialism as being about the creation of the possibility for the establishment of a regime of property-in-common. Without getting into details of Qu's language reform proposals, and as Yurou Zhong confirms in her meticulous study thereof, Qu's objection to proposals for language reform that took the Peking dialect as the standard was based in his "championing of dialect equality" as well as in his opposition to "the hegemony of the national language." 18 In Qu's collaboration with Soviet linguist Kolokolov - whom he regularly called comrade/tongzhi - it is possible to see the abstract commitments to horizontality in language reform translated into concrete personal practice. ${ }^{19}$

This insistence on what we might call the comradely relations in language carried into Qu's conceptualization for the creation of a "proletarian language" that could transcend region and establish a new universal class norm for socialism in China. For the initial period, Qu was concerned to allow for equal co-existence among languages. As the ideas for language horizontality deepened, Qu's proposals became more enmeshed in the actual class character of language. As Zhong has documented and argued, then, the emergence of the problem of "massification" (dazhonghua 大众化) in the early 1930s was integral to how Qu conceptualized the problem of Latinization and the reform of language in China. This argument became a hallmark of Qu's debates with Mao Dun 茅盾 and others who wished to maintain an "allied" relation between intellectuals and the proletariat - where the two classes remained separate and separable. Against Mao Dun's argument, $\mathrm{Qu}$ argued that the proletariat needed to be the class into which intellectuals folded themselves, rather than intellectuals being the class to which the proletariat needed to conform. Qu believed in the capacity

16 See Zhong 2019.

17 Qu 1923, 57. The original name of the essay was "Zi minzhi zhuyi zhi shehui zhuyi" (From people's rule to socialism). Qu himself revised the name of the essay for inclusion in an anthology. Invoking minquan zhuyi, one of Sun Yat-sen's Three Principles of the People, marks a clearer engagement with the discursive and political debates of his day.

18 Zhong 2019, 72.

19 Ibid., 83. 
of the proletariat's right to self-represent through a language that was theirs and that would become normatively hegemonic. ${ }^{20}$ Thus, for $\mathrm{Qu}$, language reform and the possibility of proletariat self-expression in the pursuit of massification and socialism were one and the same goal. This political, cultural and social goal cannot be disaggregated without doing epistemic and, more importantly, class violence to the then-active and prospective socialist project of forming a regime of property-in-common. While of course the ideals of Latinization, of proletariat language and of massified socialism in the terms just discussed were never actually implemented and rarely even practised by their proponents, nevertheless, for the purpose of delineating the potentials for an emergent "comrade" politics it is important to note Qu's insistence that horizontality - the non-hierarchy among spoken languages and the living process thereby inaugurated and concretized - be the principle of creative cultural and political energy as well as of theoreticalideological commitment.

Third, then, in his theory of translation, which was famously debated through a private and public engagement with Lu Xun 鲁迅 in a series of letters always beginning with the heartfelt salutation "Dear Comrade" or "My dear Comrade," $\mathrm{Qu}$ was clear that rendering one language into another needed to be a collective endeavour, one that created a new language. As Qu wrote to Lu Xun in 1931, "Translation - in addition to introducing the content of the original to Chinese readers - has another important function, that is, helping us create a new modern Chinese language." ${ }^{21}$ For $\mathrm{Qu}$, language created in and through translation was to become part of a living language of the present - in Barlow's evocative phrase, it was "to introduce foreignness and newness into the haunted house of Chinese hanzi [汉字]" in a way that produced the possibility not only for communication but for class/political expression. ${ }^{22}$ While the discussion between $\mathrm{Qu}$ and $\mathrm{Lu}$ Xun is usually understood through the problem of "fluency" versus "accuracy" in translational practice, for my purposes here, we can grasp translation in Qu's understanding as a way to activate the principle of collective creation, or what the filmmaker Zheng Junli 郑君里 later was to term "creative friendship" (chuangzao de youyi 创造的友谊) as a mode of inter-subjective transformation in cinematic production. ${ }^{23}$ This principle of collective creation animated Qu's most radical proposals about how language and practice were to be merged into a politically egalitarian form, that in turn informed his consistent attention to the historical materialist and philosophical dimensions to words, concepts and language - as spoken, written and translational forms.

Qu's conviction that "knowledge" (zhishi 智识) should not be monopolized as the private possession of the few, and that it had to be "liberated," to use Barlow's word, to be appropriated socially by all for all in the process of political

20 For the relevant documents and debates, see Wen 1987.

21 Qu 2004[1931], 153.

22 Barlow 2016, 260.

23 Qian 2021. 
transformation, is the ultimate expression of his commitments to comradely or non-hierarchical social relations. ${ }^{24}$ While this reading of $\mathrm{Qu}$ does not engage the complex ways in which he worked through the various conundrums of Marxist philosophy (a task that other scholars have engaged), it does address in a certain way Qu's belief in "the capacity of humans to consciously plan and then strive for a particular future." 25 Finally, even in 1927, as Party leader, when the pale, weak and tubercular $\mathrm{Qu}$ was confronted with the necessity to turn to armed struggle in the 7 August Politburo meeting (in the face of the KMTCCP split and the White Terror), Qu pushed for this policy with the clarity that it doomed him personally to a martyr's death. In 1935, he was resolute in his personal sacrifice for the Communist Party and his refusal to purchase his freedom by turning on his comrades as he faced execution, indicating how he lived and practised his politics to the very end. This can be seen as a form of personal heroism to be sure, but more clearly and radically, it was Qu practising his self-proclaimed superfluidity: his displacement and alienation from his "proper" place as petit bourgeois intellectual in his pursuit of a revolutionary politics of the comradely collective.

Were these positions and politics without contradiction? They could not possibly be. But it is in the contradiction expressed in the non-hierarchical promise of the comrade relation, between an alienation from individual life and a conviction in the necessity for mass revolutionary/collective action, that we can find Qu's most radical contributions to Communist practice and thinking from the very inauguration of the Party in 1921 as a political organization and mass mobilizational principle.

\section{Where Have All the Comrades Gone?}

Infamously, in late 2016, the current "core" leader of China, Xi Jinping 习近平, begged members of the CCP to re-establish the habit of calling each other "comrade." The directive, issued on 27 October 2016, superficially exhorted the increasingly hierarchical Party organization and entitled Party members to return to more egalitarian roots to combat the emergence and entrenchment of a number of baleful trends. The relevant document says:

In the new circumstances, life inside the Party apparatus is generally good. At the same time and for some time already, Party life has exhibited the emergence of problems. These include: among some Party members, not excluding some high-up cadres, there has been a slackening of ideals, a lack of loyalty to the Party, a weakening of discipline, a distancing from the masses, domineering behaviour, fraud and trickery, indolence and inaction, individualism, decentralism, liberalism, unprincipled humanism (haoren zhuyi), factionalism, sectarianism, gold worshiping of various sorts, formalism, bureaucratism, hedonism and a love of luxury, nepotism, jockeying for position, buying and selling positions, paying for votes and currying favour, indiscriminate use of power, corruption and enrichment, illegal and licentious behaviour, among others. Particularly among high- and mid-level cadres, there has emerged unchecked political 
ambition, lust for power, conspiring and manipulating [to enhance power], cliquishness, factional ganging up, power-seeking and other political plotting activities. ${ }^{26}$

In the face of all this lack of common will - tong zhi in a revolutionary sense (although perhaps plenty of common will expressed individually to expropriate, accumulate, privatize and appropriate public and ill-gotten properties) - the call for restoration of the salutation comrade/tongzhi appears as no more than window dressing, empty rhetoric, or worse. This restoration is not meant to be socially or politically transformative: there is no political or materialist basis in which a revolutionary transformation can take root. Instead, this is an attempt to dress today's completely different ideological commitments - capitalist accumulation, social inequality, national wealth, global hegemony - in the guise of previous and now thoroughly discarded political ideals - socialism, global equality, social equity and internationalism. Moreover, where "comrade" used to name the precarity of political organizing - a displacement - today all it names is the supposedly proper and fully hegemonic grip on power of the Party in China's current form of governance. The point is not that the socialist ideal was ever reached; the point is that the exhorted return to "comrade" as a state-sanctioned salutation is the empty signifier of a pursuit of communism evacuated of all relevant content.

These days, the Party is a vehicle of individual advancement and an organized mode of looting the public and accumulating/conserving individual wealth for social and state power for the few. There is nothing radically revolutionary about it, and nothing egalitarian or non-hierarchical either. In presiding over some of the most rapid and spectacularly unequal accumulations of wealth known to mankind, and in directing the dispossession not only of the Chinese people of their collective property but increasingly the dispossession of peoples all over the world of their indigenous and nationalized properties, the Chinese Communist Party has decidedly not lived up to its inaugural promise of equality and egalitarian relations. In its verticality, its hierarchies, its entitlements, its censorships as well as in its embrace of the parts of "Chinese tradition" that call for obedience and quiescence, patriarchy and masculinist statism, in addition to its wholesale encouragement of (Han) ethno-nationalism, its suppression of Uyghurs and Tibetans among others, and the betrayal of democratic possibility in Hong Kong, the Party has also betrayed its roots in global class revolution to overthrow rather than strengthen capitalism in China and the world. In this circumstance, "comrade" as a Party political principle can only be a hollow echo of a different political past and a different potential future. It can only be a cynical call for policing rather than liberating language and social practice from the prison house of class society.

26 "Guanyu xin xingshi xia dang nei zhengzhi shenghuo de ruogan zhunze, 2016 nian 10 yue 27 ri Zhongguo gongchangdang di shiba jie Zhongyang weiyuanhui di liu ci quanti huiyi tongguo" (Several guidelines for internal Party political life under the new circumstances, adopted at the Sixth Plenary Session of the 18th CCPCC, 27 October 2016). Renmin ribao, 27 October 2016, reprinted on Renminwang, http://www.people.com.cn/. Accessed 3 July 2020. Author's translation. 
The principle of "comrade," however, retains its power to name and shape a present striving as well as future ideal in a universal, horizontal and egalitarian mode in its current social usage as LGBTQ identity and being-in-common. As Hongwei Bao writes, comrade/tongzhi queers political subjectivity by appropriating a socialist-era desire and reconfiguring it for an internationalist moment of activism across the geographies of Hong Kong, Taiwan, Singapore and diasporic societies. ${ }^{27}$ In places where socialism had never been practised and, indeed, had been banned (Taiwan, Singapore, etc.), and with full awareness that socialism as practised in China during the Maoist period explicitly had excluded LGBTQ identities, tongzhi nevertheless now can expressively produce a politics of social displacement by relocating into the everyday a radically contestatory identity-in-common. The re-placing of comrade/tongzhi reconceptualizes this relation for a new world of radical struggle, transformative possibility and affective hope. Unfortunately, this is a new world that the CCP can no longer plausibly embody and to which it cannot lay contemporary claim. Indeed, it is a new world that the CCP is actively working to thwart and suppress.

\section{Acknowledgements}

I thank Patricia Thornton for asking me to write a piece for this occasion, and for so firmly holding me to my agreement to do so. I am most grateful to Qian Ying for our pandemic-year walks and talks during which I worked out the arguments here on offer; and to Jodi Dean, whom I've met only once, but whose book, Comrades, inspired me to think along the lines here explored. In comradely fashion, Aminda Smith and Fabio Lanza each read an early draft, critiqued and thereby improved this contribution. Reader \#1's comments were extremely helpful and I took up most of their suggestions; meanwhile, proverbial Reader \#2 hated the piece: I heeded one or two of their specific suggestions while their vehemence encouraged me to persist on the path they so despise.

\section{Conflicts of interest}

None.

\section{Biographical note}

Rebecca E. KARL is professor of history at New York University, NY. She is author, most recently, of China's Revolutions in the Modern World: A Brief Interpretive History (Verso, 2020), and is co-founder of the Critical China Scholars (criticalchinascholars.org) collective as well as a founding editorial member of positionspolitics.org. 


\begin{abstract}
摘要: 本文深入思考 “同志” 这一政治术语在中共早期历史中所表述的理想 社会关系。本文以篧秋白作为这一时期马克思主义政治思想家与共产党组 织者的代表, 其关于所谓 “多余”、翻译以及语言的理论表明了他对同志 关系这一问题的关注。本文进一步指出, 尽管近年来习近平极力倡导重新 启用作为政治术语的 “同志”，但反而是当代中国 LGBTQ 群体对 “同 志”一词的挪用为这个发轫于一个世纪前的乌托邦理想保留了重生的可 能。
\end{abstract}

关键词: 马克思主义; 同志; 篗秋白; LGBTQ; 群体; 中国共产党

\title{
References
}

Bao, Hongwei. 2018. Queer Comrades: Gay Identity and Tongzhi Activism in Postsocialist China. Copenhagen: Nordic Institute of Asian Studies Press.

Barlow, Tani. 2016. "'History's coffin can never be closed': Qu Qiubai translates social science." Boundary 2, 43(3), 253-286.

Bensaiid, Daniel. 2015. An Impatient Life: A Memoir (D. Fernbach (trans.)). London: Verso.

Dean, Jodi. 2019. Comrade: An Essay on Political Belonging. New York: Verso.

Jameson, Frederic. 1981. The Political Unconscious: Narrative as a Socially Symbolic Act. Ithaca, NY: Cornell University Press.

Knight, Nick. 2005. Marxist Philosophy in China from Qu Qiubai to Mao Zedong, 1923-1945. Dordrecht: Springer.

Kohlenberg, Paul Joscha. 2016. "The use of 'comrade' as a political instrument in the Chinese Communist Party, from Mao to Xi." The China Journal 77, 72-92.

Liang, Qichao. 1984[1901]. "Bianfa tongyi" (On reforms). In Yinbingshi wenji (Essays from the Ice-Drinker's Studio), Vol. 1. Taipei: Zhonghua shuju.

Ma, Mingchong. 2018. "Zhonggong huayu tixizhong 'tongzhi' gainian de lishi liubian" (The evolution of the concept and history of "comrade" in the Chinese Communist discursive system), 19 July, http://www.dswxyjy.org.cn. Accessed on 18 July 2020.

Patterson, David. 1995. Exile: The Sense of Alienation in Modern Russian Letters. Lexington, KY: University of Kentucky Press.

Pickowicz, Paul. 1981. Marxist Literary Thought in China: The Influence of Ch'u Ch'iu-bai. Berkeley, CA: University of California Press.

Qian, Ying. 2021. "Chūgoku ni okeru eiga kantoku zō" (Envisioning the film director in China). In Haruo Shirane and Tomi Suzuki (eds.), Sakusha to wa nanika: Keishō, senyū, kyōdōsei (What is an "Author"? Transmission, Ownership and Collectivity). Tokyo: Iwanami Shoten.

Qiu, Jin. 1998[1907]. “Excerpts from Stones of the Jingwei Bird.” In Amy D. Dooling and Kristina M. Torgeson (eds.), Writing Women in Modern China: An Anthology of Women's Literature in the Early Twentieth Century. New York: Columbia University Press, 39-79.

Qu, Qiubai 1923. "Zi minquan zhuyi zhi shehui zhuyi” (From the principle of democracy to socialism). Xin qingnian 2.

Qu, Qiubai. 2004[1931]. "On translation - a letter to Lu Xun.” In Leo Tak-Hung Chan, Twentieth-century Chinese Translation Theory: Modes, Issues, and Debates. Amsterdam: John Benjamins Publishing Company, 153.

Qu, Qiubai. 2006[1935]. Superfluous Words (Jamie Greenbaum (trans.)). Canberra: ANU Press.

Rodekohr, Andy. 2017. "The execution of Qu Qiubai.” In David Der-wei Wang (ed.), A New Literary History of Modern China. Cambridge, MA: Belknap Press, 400-406.

Ross, Kristin. 2002. May '68 and its Afterlives. Chicago: University of Chicago Press. 
28 The China Quarterly, 248, November 2021, pp. 16-28

Roux, Alain, and Xiaoling Wang. 2006. “Qu Qiubai (1899-1935), 'Des mots de trop' (duoyu de hua). L'autobiographie d'un intellectuel engagé chinois." China Perspectives 67. DOI: https://doi.org/10. 4000/chinaperspectives. 1051.

Wen, Zhenting (ed.). 1987. Wenyi dazhonghua wenti taolun ziliao (Materials on the Discussions of the Massification of Literature and Art). Shanghai: Shanghai wenyi chubanshe.

Zhong, Yurou. 2019. Chinese Grammatology: Script Revolution and Literary Modernity, 1916-1958. New York: Columbia University Press. 